\title{
IL1R1 Gene
}

National Cancer Institute

\section{Source}

National Cancer Institute. IL1R1 Gene. NCI Thesaurus. Code C38911.

This gene is involved in a variety of cytokine induced immune and inflammatory responses. 